\title{
Broom Snakeweed: Effect on Shortgrass Forage Production and Soil Water Depletion
}

\author{
DARRELL N. UECKERT
}

\begin{abstract}
Perennial shortgrasses were delayed in responding to removal of a dense broom snakeweed population $\left(387 / \mathrm{m}^{2}\right)$ because of low initial vigor. However, after 1 year, grass production increased by $107 \%(1,175 \mathrm{~kg} / \mathrm{ha})$ and after 2 years, by $324 \%(2,201 \mathrm{~kg} / \mathrm{ha})$ compared to undisturbed stands. Reducing snakeweed density by 25 or $50 \%$ did not affect forage production during the 2 -year study. Estimated carrying capacity of the shortgrass rangeland was increased from 1 A.U./26 ha to 1 A.U./6.1 ha by the second year after complete removal of broom snakeweed. Juvenile broom snakeweed plants utilized soil water from the upper 15 to $45 \mathrm{~cm}$. Soil water depletion was increased after perennial grasses regained vigor following complete removal of snakeweeds. Precipitation-use efficiency for production of usable forage was $\mathbf{2 . 1}$ and 4.3 times greater on broom snakeweed-free rangeland than on infested rangeland at 1 and 2 years, respectively, following removal of snakeweed.
\end{abstract}

Broom snakeweed [Xanthocephalum sarothrae (Pursh) Shinners], also referred to as perennial broomweed, turpentineweed, and slinkweed, is common on rangelands throughout the western two-thirds of Texas and west to California, north to Canada and south into Mexico (Ragsdale 1969). Broom snakeweed, a short-lived, perennial half-shrub, often increases in abundance following heavy grazing of shortgrass rangeland (Stoddart et al. 1975). The species aggressively invades disturbed areas but its populations are cyclic and it is not a reliable indicator of overgrazing (Jameson 1970; Vallentine 1971).

Author was associate professor, Department of Range and Wildlife Management, Texas Tech University, when the research was initiated and associate professor, Texas A\&M University Agricultural Research and Extension Center, Route 1, Box 950, San Angelo, Texas 76901 , when the research was finished.

This report was approved by the dean, College of Agricultural Sciences, Texas Tech University as T-9-192, and by the director, Texas Agricultural Experiment Station, as TA No. 14191

The author expresses appreciation to Rebecca Post, Steve Post, Dolores Ueckert, Steve Whisenant. Randal Papasan, and Charles Allen for their valuable assistance with this study.

Manuscript received June 16, 1978
Extensive areas of rangeland in the western half of Texas became heavily infested with broom snakeweed and threadleaf snakeweed [X. microcephalum (DC.) Shinners] after the drought of the 1950's (Ragsdale 1969). These populations have persisted, but stand densities vary with weather cycles. Both species are toxic to cattle, sheep, goats, and several other species of animals (Sperry et al. 1964). The most common problem is abortion in cattle, and this is most severe on sandy soils, where as many as $60 \%$ of the pregnant cows abort, delivering dead or small, weak calves (Sperry et al. 1964).

Control of broom snakeweed with herbicides has been erratic (Allen and Dollahite 1959). Sperry and Robison (1963) reported that amine and ester formulations of 2,4-D [(2,4-dichlorophenoxy) acetic acid] in water at $1.12 \mathrm{~kg} / \mathrm{ha}$ were the most effective herbicides then available, but that optimum growing conditions at time of spraying and, in most cases, two successive treatments were necessary for control of broom snakeweed. Schmutz and Little (1970) achieved excellent control of broom snakeweed in central Arizona with $0.56 \mathrm{~kg} / \mathrm{ha}$ of picloram (4-amino-3,5,6-trichloropicolinic acid) as granules applied from September through December and as foläir sprays applied in April. They reported that picloram was two to four times more toxic to broom snakeweed than 2,4-D or 2,4,5-T [2,4,5-trichlorophenoxy) acetic acid]. Gesink et al. (1973) reported excellent control of broom snakeweed on shortgrass rangeland in Wyoming with June application of picloram sprayed at $0.56 \mathrm{~kg} / \mathrm{ha}$ and with picloram $+2,4-\mathrm{D}(0.28+1.12$ $\mathrm{kg} / \mathrm{ha}$ ). Boyd et al. (1976) reported that fall, winter, or spring application of tebuthiuron ( $N$-[5-(1,1-dimethylethyl)-1,3,4thiadiazol-2-yl]- $N, N^{\prime}$-dimethylurea) sprayed at 0.14 to 0.28 $\mathrm{kg} / \mathrm{ha}$ reduced broom snakeweed standing crop biomass by $80 \%$ on shortgrass rangeland. Dwyer (1967) reported that burning in June killed $96 \%$ of the broom snakeweed plants in a blue grama (Bouteloua gracilis H.B.K.) range in New Mexico, but that burns in October, January and April killed only 35, 25, and 
$45 \%$, respectively. Hopkins et al. (1948) reported that burning shortgrass rangeland in western Kansas effectively controlled broom snakeweed.

Most studies on broom snakeweed have dealt with control or toxicity. The objectives of this study were to evaluate competition between broom snakeweed and perennial grasses on shortgrass prairie rangeland and to study the effect of broom snakeweed on soil water depletion.

\section{Methods and Materials}

This study was conducted on the rangeland portion of the Texas Tech University Farm in Lubbock County. The site supported a semiarid shortgrass community dominated by honey mesquite (Prosopis glandulosa Torr. var. glandulosa), blue grama, buffalograss (Buchloe dactyloides Nutt.), and broom snakeweed. The mean annual precipitation is $48 \mathrm{~cm}$. The soil is an Amarillo fine sandy loam (fine loamy mixed, thermic family of Aridic Paleustalfs).

The study area has been heavily grazed by cattle during 1974-75, and abundant precipitation during the fall-winter period resulted in a dense ( 387 seedlings $/ \mathrm{m}^{2}$ ), relatively homogeneous stand of broom snakeweed seedlings in the spring of 1975 . On July 30 and 31,1975 , broom snakeweed plant density was reduced by $0,25,50$, or $100 \%$ (based on original density) on $3 \mathrm{~m}$ by $3 \mathrm{~m}$ plots arranged in a randomized complete block design with three replications of each density reduction treatment. Seedlings were killed by cutting slightly below the soil surface with a sharp knife and were removed from the plots. A $1-\mathrm{m}$ border around each plot was plowed with a garden tiller to minimize edge effect. All mesquite within $15 \mathrm{~m}$ of the plots were killed. The study area was fenced to exclude livestock and lagomorphs on August 8, 1975. A high level of feeding activity by desert termites (Gnathamitermes tubiformans), evidenced by an abundance of mud casts and sheetings over dead and live herbaceous vegetation, occurred in the spring of 1976. Since the influence of broom snakeweed density reduction treatments upon termite feeding activity was not known, it was deemed essential to eliminate termites from all experimental plots. This was accomplished by spraying all plots with chlordane (octachloro-4, 7-methanotetrahydroindane) at $3.37 \mathrm{~kg}$ a.i./ha in 3.8 litters of water per plot on June 21, 1976.

Density of broom snakeweed was determined immediately after mechanical thinning by counting individual plants in $0.25-\mathrm{m}^{2}$ quadrats. From 5 to 13 quadrats were necessary to estimate mean density on a plot adequately. Also, counting consistently underestimated actual numbers of broom snakeweed plants because of the difficulty in discerning an individual plant. Count data were corrected to actual density using regression equations obtained by counting (independent variable), then uprooting and re-counting plants (dependent variable), in 10 quadrats outside the experimental plots. Reduced densities were maintained by monitoring broom snakeweed density on August 25 and October 20, 1975, and on May 20, 1976, and thinning when necessary.

A point frame was used on October 22, 1975, to obtain cover repetition, the number of aerial hits per pin, for broom snakeweed and perennial grasses on the study plots. One hundred randomly located point samples were recorded for each plot. Cover repetition is highly correlated with aboveground biomass (Conant and Risser 1974). Standing crop biomass (oven-dry) of perennial grasses and broom snakeweed was determined on each plot by clipping vegetation to ground line in 10 randomly located $0.1-\mathrm{m}^{2}$ quadrats on the western half of each plot at 1 year post treatment (August 20, 1976), and in 10 randomly located $0.1-\mathrm{m}^{2}$ quadrats on the eastern half of each plot at 2 years post treatment (July 19, 1977). Vegetation samples were oven-dried at $60^{\circ} \mathrm{C}$ for $72 \mathrm{hr}$ before weighing.

Soil water was determined by the gravimetric method (Gardner 1965 ) from three, randomly located, $2.5-\mathrm{cm}$ diam soil cores for each $15-\mathrm{cm}$ increment to a depth of $120 \mathrm{~cm}$ on each plot on October 9,1975 , January 13, 1976, April 7, 1976, and August 18, 1976 (3, 6, 9, and 13 months post treatment), and to a depth of $90 \mathrm{~cm}$ on July 20, 1977 (2 years post treatment). Soil bulk density values for each $15-\mathrm{cm}$ increment, determined from five, $5.4-\mathrm{cm}$ diam by $5.9 \mathrm{~cm}$, undisturbed soil cores by the core method (Blake 1965) were used for computing volumetric soil water. Soil water at $-1 / 3,-1$ and -15 bars for the Amarillo fine sandy loam profile was calculated from data collected less that $400 \mathrm{~m}$ from the study area on the same soil unit (Bryant 1977). Precipitation was recorded on the study area after each precipitation event. Precipitation-use efficiency was calculated as the units $(\mathrm{kg} / \mathrm{ha})$ of herbage produced per unit $(\mathrm{cm})$ of precipitation received during the preceding 12-month period.

Data on cover repetition, standing crop biomass and soil water were subjected to analysis of variance. Multiple range tests were used to separate treatment means where appropriate.

\section{Results and Discussion \\ Broom Snakeweed Density and Mortality}

In August 1975, the original mean population density of broom snakeweed seedlings was $387 / \mathrm{m}^{2}$ (range 332 to $444 / \mathrm{m}^{2}$ ). Similar stand densities were common throughout the Texas Panhandle and eastern New Mexico. By October 1975, the mean density was 242 seedlings $/ \mathrm{m}^{2}$ (37.5\% mortality). Precipitation during the period June through September 1975 (29 $\mathrm{cm}$, Fig. 1), was above average, but apparently was not adequate to support the initial high density of seedlings. Natural mortality of seedlings from August to October 1975, was $18.1 \%$ and $8.3 \%$ on plots where seedling density was reduced by $25 \%$ and $50 \%$, respectively. Mortality from October 20, 1975, through May 20, 1976, was $24.8 \%$ on the undisturbed plots and $4.4 \%$ and $0 \%$ on plots where density was reduced by $25 \%$ and $50 \%$, respectively. Only $9.6 \mathrm{~cm}$ of precipitation was received during the period October 1975 through May 1976. These data indicate that intraspecific competition within the broom snakeweed population was intense and that reducing plant density by $25 \%$ or $50 \%$ greatly reduced this competition. Density data were not recorded after May 1976, but very few dead plants and no new seedlings were present in July 1977 on any of the plots.

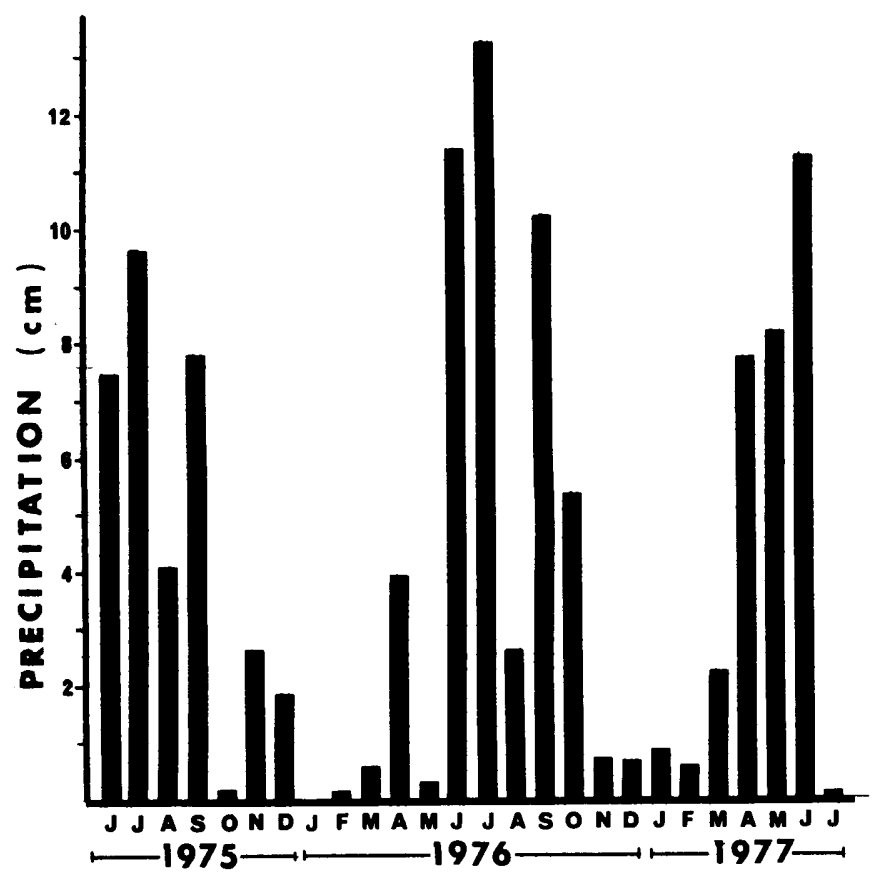

Fig. 1. Precipitation (monthly totals) received on experimental plots from June, 1975, through July, 1977. Total precipitation for June, 1976, includes 8.46 cm applied to each plot by flood irrigation. 
Table 1. Cover repetition (mean number of hits/pin) for perennial grasses and hroom snakeweed in October 1975 following various thinning treatments in July 1975.

Broom snakeweed density reduction (\%)

$0^{2}$
25
50
100
25

100

Mean no. hits/pin

Perennial grasses Broom snakeweed

$\begin{array}{ll}0.95 \mathrm{a}^{3} & 0.61 \mathrm{~b}^{3} \\ 0.88 \mathrm{a} & 0.58 \mathrm{~b} \\ 0.76 \mathrm{a} & 0.43 \mathrm{~b} \\ 0.87 \mathrm{a} & 0.00 \mathrm{a}\end{array}$

Initial mean density of broom snakeweed $\left(387 / \mathrm{m}^{3}\right)$ was reduced to $242 / \mathrm{m}^{2}$ by Octoher 20.1975 , by natural mortality in undisturbed plots.

Means within a column followed by similar lower case letters are not significantly different at $P<0.05$.

\section{Biomass and Cover Repetition of Herbage}

Reducing density of broom snakeweed plants had no effect on canopy cover repetition of perennial grasses at the end of the first growing season (October 1975, Table 1). Perennial grasses were in extremely low vigor when densities of broom snakeweed were reduced and did not respond immediately even though considerable precipitation was received during this period (Fig. 1). Statistically significant $(P<0.05)$ reduction of cover repetition of broom snakeweed in October 1975 was achieved only by the complete removal treatment.

After 13 months (August 1976), standing crop of perennial grasses was significantly increased $(P<0.05)$ only on plots where all broom snakeweed plants had been removed (Table 2; Fig. 2). Complete removal increased production of perennial grasses by $1,175 \mathrm{~kg} / \mathrm{ha}(107 \%)$, whereas $25 \%$ and $50 \%$ density reduction did not affect perennial grass production (Table 2). Twenty-five or $50 \%$ reductions of broom snakeweed density did not significantly alter standing crop of this species compared to undisturbed plots, but broom snakeweed biomass was significantly $(P<0.05)$ higher where density had been reduced by $25 \%$ as compared to $50 \%$ (Table 2 ). Reducing density of broom snakeweed did not reduce its biomass or increase perennial grass production proportionately. Reducing broom snakewecd density by $50 \%$ resulted in a $29 \%$ decrease in its biomass at 13 months after treatment. Decreasing broom snakeweed density by $25 \%$ appeared to have a stimulatory effect on its production,

Table 2. Standing crop (kg/ha) of perennial grasses and broom snakeweed in August 1976 and in July 1977 following application of various thinning treatments in July 1975.

Broom snakeweed density reduction (\%)

Standing crop $(\mathrm{kg} / \mathrm{ha})$

Perennial grasses Broom snakeweed

\begin{tabular}{crr} 
& \multicolumn{2}{c}{ August 1976} \\
$0^{2}$ & $1094 \mathrm{a}^{3}$ & $2377 \mathrm{bc}$ \\
25 & $1094 \mathrm{a}$ & $2736 \mathrm{c}$ \\
50 & $906 \mathrm{a}$ & $1686 \mathrm{~b}$ \\
100 & $2269 \mathrm{~b}$ & $0 \mathrm{a}$ \\
& & July 1977 \\
$0^{4}$ & $679 \mathrm{a}$ & $2473 \mathrm{bc}$ \\
25 & $704 \mathrm{a}$ & $3084 \mathrm{c}$ \\
50 & $1054 \mathrm{a}$ & $2200 \mathrm{~b}$ \\
100 & $2880 \mathrm{~b}$ & $0 \mathrm{a}$
\end{tabular}

"Initial mean density of broom snakeweeds on undisturbed plots was $387 / \mathrm{m}^{2}$, natural mortality had reduced mean density on undisturbed plots to $182 / \mathrm{m}^{3}$ by May 20,1976 . Means within a column, for the date indicated, followed by similar lower case letters are mot significantly different at $P<0.05$.

'Population density of hroom snakeweeds on control plots was approximately $180 / \mathrm{m}^{2}$ in July 1977. as evidenced by a $15 \%$ increase in standing crop (Table 2 ).

At 2 years after treatment, complete removal of broom snakeweed increased standing crop biomass of perennial grasses by $2,201 \mathrm{~kg} / \mathrm{ha}(324 \%)$ (Table 2$)$. Reducing broom snakeweed density by $25 \%$ or $50 \%$ had no significant $(P<0.05)$ effect on perennial grass production compared to that in undisturbed plots. Broom snakeweed biomass was not significantly affected by reducing its density $25 \%$ or $50 \%$ (Table 2 ). Biomass of individual broom snakeweed plants increased as their density decreased within the density range encountered in this study. Broom snakeweed plants were more competitive with perennial grasses in the second year of their life cycle than in the first year, possibly due to extension and expansion of their root systems or to greater shading effect as their aboveground portions increased in size.

Complete removal of broom snakeweed increased perennial grass production by $1,175 \mathrm{~kg} / \mathrm{ha}(1,048 \mathrm{lb} / \mathrm{acre})$ in 1976 and by $2,201 \mathrm{~kg} / \mathrm{ha}(1,964 \mathrm{lb} / \mathrm{acre})$ in 1977 . Assuming that only $25 \%$ of the total available herbage will be utilized by livestock (the remainder being consumed by insects and other herbivores, left standing dead, deposited as litter, lost due to trampling or contaminated with dung, etc.), and that an animal unit (A.U.) requires $12.02 \mathrm{~kg}(26.5 \mathrm{lb})$ of forage (dry weight) per day, complete control of broom snakeweed increased the estimated carrying capacity of this shortgrass rangeland in 1976 from 1 A.U./16 ha to A.U./7.7 ha and from A.U./26 ha to 1 A.U./6.1 ha in 1977.

Jameson (1966) reported that reducing broom snakeweed and Cooper actinea (Hymenoxis cooperi) standing crop by $90 \%$ and $60 \%$ with selective herbicides, respectively, increased blue grama production by 14 to $38 \%$ and also increased production of bottlebrush squirreltail [Sitanion hystrix (Nutt.) J.G. Smith] and forbs in a juniper-pinyon woodland in Arizona. Jameson reported that each kilogram of half-shrubs killed by herbicides was replaced by less than $0.5 \mathrm{~kg}$ of herbaceous plants. He speculated that larger responses of herbaceous plants to the treatments would have occurred if density of half-shrubs had been greater. In our study, each kilogram of broom snakeweed killed was replaced by $0.49 \mathrm{~kg}$ of perennial grass in 1976 and by $0.89 \mathrm{~kg}$ of perennial grass in 1977. Gesink et al. (1973) reported that perennial grass production was 300 to $600 \%$ greater on shortgrass rangeland in Wyoming where broom snakeweed had been controlled for 5 years with one application of various rates of picloram alone or in combination with 2,4-D, as compared to undisturbed rangeland.

\section{Soil Water Depletion}

In October 1975 (3 months after treatment), with complete removal of broom snakeweed, soil water depletion was significantly $(P<0.05)$ decreased in the 15 to 30 and 30 to $45-\mathrm{cm}$ increments as compared to undisturbed, $25 \%$, and $50 \%$ density reductions (Table 3 ). Since perennial grasses had not responded to complete removal of broom snakeweed at this time, these data suggest that juvenile broom snakeweed plants were utilizing soil water from the 15 to $45-\mathrm{cm}$ increment of the soil profile. Reducing broom snakeweed density by 25 to $50 \%$ did not affect soil water depletion as compared to undisturbed stands.

In January 1976, complete removal of broom snakeweed resulted in a significant decrease in soil water depletion in the 0 to $15-\mathrm{cm}$ increment as compared to 25 to $50 \%$ density reduction, but none of the treatments were significantly different from the untreated plots (Table 3). Soil water depletion was significantly greater in the 15 to $30-\mathrm{cm}$ increment where broom snakeweed density was reduced 25 or $100 \%$ compared to the 
Table 3. Soil water $(\mathrm{cm})$ at various times after treatment, by depths, and as affected by thinning or complete removal of broom snakeweed in July $1975^{\prime}$.

\begin{tabular}{|c|c|c|c|c|}
\hline \multirow[b]{2}{*}{ Soil depth $(\mathrm{cm})$} & \multicolumn{4}{|c|}{ Broom snakeweed density reduction (\%) } \\
\hline & 0 & 25 & 50 & 100 \\
\hline & \multicolumn{4}{|c|}{ October 1975} \\
\hline $0-15$ & $1.0+a b^{\prime \prime}$ & $0.89 \mathrm{a}$ & $0.97 \mathrm{ab}$ & $1.14 \mathrm{~b}$ \\
\hline $15-30$ & $1.23 \mathrm{a}$ & $1.23 \mathrm{a}$ & $1.23 \mathrm{a}$ & $1.60 \mathrm{~b}$ \\
\hline $30-45$ & $1.51 \mathrm{a}$ & $1.52 \mathrm{a}$ & $1.44 \mathrm{a}$ & $1.71 \mathrm{~b}$ \\
\hline $45-60$ & $1.50 \mathrm{a}$ & $1.49 \mathrm{a}$ & $1.45 \mathrm{a}$ & $1.46 \mathrm{a}$ \\
\hline $60-75$ & $1.44 \mathrm{a}$ & $1.46 \mathrm{a}$ & $1.41 \mathrm{a}$ & $1.43 \mathrm{a}$ \\
\hline $75-90$ & $1.50 \mathrm{a}$ & $1.47 \mathrm{a}$ & $1.48 \mathrm{a}$ & $1.51 \mathrm{a}$ \\
\hline $90-105$ & $1.64 \mathrm{a}$ & $1.54 \mathrm{a}$ & $1.55 \mathrm{a}$ & $1.70 \mathrm{a}$ \\
\hline $105-120$ & \multicolumn{4}{|c|}{ January 1976} \\
\hline $0-15$ & $1.67 \mathrm{ab}$ & $1.37 \mathrm{a}$ & $1.48 \mathrm{a}$ & $1.82 \mathrm{~b}$ \\
\hline $15-30$ & $2.05 \mathrm{~b}$ & $1.59 \mathrm{a}$ & $1.81 \mathrm{ab}$ & $1.74 \mathrm{a}$ \\
\hline $30-45$ & $1.91 \mathrm{~b}$ & $1.61 \mathrm{a}$ & $1.73 \mathrm{ab}$ & $1.75 \mathrm{ab}$ \\
\hline $45-60$ & $1.63 \mathrm{a}$ & $1.55 \mathrm{a}$ & $1.58 \mathrm{a}$ & $1.62 \mathrm{a}$ \\
\hline $60-75$ & $1.56 \mathrm{a}$ & $1.51 \mathrm{a}$ & $1.48 \mathrm{a}$ & $1.54 \mathrm{a}$ \\
\hline $75-90$ & $1.55 \mathrm{a}$ & $1.54 \mathrm{a}$ & $1.51 \mathrm{a}$ & $1.57 \mathrm{a}$ \\
\hline $90-105$ & $1.73 \mathrm{a}$ & $1.73 \mathrm{a}$ & $1.71 \mathrm{a}$ & $1.64 \mathrm{a}$ \\
\hline \multirow[t]{2}{*}{$105-120$} & $1.62 \mathrm{a}$ & $1.73 \mathrm{a}$ & $1.82 \mathrm{a}$ & $1.76 \mathrm{a}$ \\
\hline & \multicolumn{4}{|c|}{ April 1976} \\
\hline $0-15$ & $0.96 \mathrm{a}$ & $0.80 \mathrm{a}$ & $0.76 \mathrm{a}$ & $0.87 \mathrm{a}$ \\
\hline $15-30$ & $1.33 \mathrm{~b}$ & $1.19 \mathrm{ab}$ & $1.05 \mathrm{a}$ & $1.18 \mathrm{ab}$ \\
\hline $30-45$ & $1.45 \mathrm{a}$ & $1.39 \mathrm{a}$ & $1.27 \mathrm{a}$ & $1.28 \mathrm{a}$ \\
\hline $45-60$ & $1.46 \mathrm{a}$ & $1.44 \mathrm{a}$ & $1.42 \mathrm{a}$ & $1.33 \mathrm{a}$ \\
\hline $60-75$ & $1.39 \mathrm{a}$ & $1.46 \mathrm{a}$ & $1.45 \mathrm{a}$ & $1.29 \mathrm{a}$ \\
\hline $75-90$ & $1.54 \mathrm{a}$ & $1.48 \mathrm{a}$ & $1.59 \mathrm{a}$ & $1.47 \mathrm{a}$ \\
\hline $90-105$ & $1.69 \mathrm{a}$ & $1.65 \mathrm{a}$ & $1.79 \mathrm{a}$ & $1.66 \mathrm{a}$ \\
\hline \multirow[t]{2}{*}{$105-120$} & $1.71 \mathrm{a}$ & $1.72 \mathrm{a}$ & $1.70 \mathrm{a}$ & $1.62 \mathrm{a}$ \\
\hline & \multicolumn{4}{|c|}{ August 1976} \\
\hline $0-15$ & $0.75 \mathrm{a}$ & $0.72 \mathrm{a}$ & $0.68 \mathrm{a}$ & $0.66 \mathrm{a}$ \\
\hline $15-30$ & $0.97 \mathrm{~b}$ & $0.90 \mathrm{ab}$ & $0.92 \mathrm{ab}$ & $0.77 \mathrm{a}$ \\
\hline $30-45$ & $1.26 \mathrm{a}$ & $1.14 \mathrm{a}$ & $1.19 \mathrm{a}$ & $1.17 \mathrm{a}$ \\
\hline $45-60$ & $1.26 \mathrm{~b}$ & $1.22 \mathrm{~b}$ & $1.16 \mathrm{ab}$ & $0.99 \mathrm{a}$ \\
\hline $60-75$ & $1.33 \mathrm{~b}$ & $1.30 \mathrm{~b}$ & $1.25 \mathrm{ab}$ & $1.15 \mathrm{a}$ \\
\hline $75-90$ & $1.34 \mathrm{a}$ & $1.38 \mathrm{a}$ & $1.33 \mathrm{a}$ & $1.25 \mathrm{a}$ \\
\hline $90-105$ & $1.51 \mathrm{a}$ & $1.57 \mathrm{a}$ & $1.50 \mathrm{a}$ & $1.48 \mathrm{a}$ \\
\hline \multirow[t]{2}{*}{$105-120$} & $1.51 \mathrm{a}$ & $1.55 \mathrm{a}$ & $1.56 \mathrm{a}$ & $1.51 \mathrm{a}$ \\
\hline & \multicolumn{4}{|c|}{ July 1977} \\
\hline $0-15$ & $0.81 \mathrm{~b}$ & $0.83 b$ & $0.81 \mathrm{~b}$ & $0.67 \mathrm{a}$ \\
\hline $15-30$ & $1.05 \mathrm{a}$ & $0.95 \mathrm{a}$ & $1.00 \mathrm{a}$ & $0.90 \mathrm{a}$ \\
\hline $30-45$ & $1.31 \mathrm{~b}$ & $1.15 \mathrm{ab}$ & $1.25 \mathrm{~b}$ & $1.03 \mathrm{a}$ \\
\hline $45-60$ & $1.30 \mathrm{~b}$ & $1.23 \mathrm{~b}$ & $1.29 \mathrm{~b}$ & $1.01 \mathrm{a}$ \\
\hline $60-75$ & $1.33 \mathrm{~b}$ & $1.27 \mathrm{~b}$ & $1.32 \mathrm{~b}$ & $1.10 \mathrm{a}$ \\
\hline $75-90$ & $1.40 \mathrm{~b}$ & $1.38 \mathrm{~b}$ & $1.36 \mathrm{~b}$ & $1.18 \mathrm{a}$ \\
\hline
\end{tabular}

Mean population density of broom snakeweed on undisturbed plots was $387 / \mathrm{m}^{3}$ in August $1975,242 / \mathrm{m}^{3}$ in October 1975 and $182 / \mathrm{m}^{3}$ in May 1976.

Means within a row followed by similar lower case letters are not significantly different all $1 \times 0.05$

undisturbed stands. Soil water depletion in the 30 to $45-\mathrm{cm}$ increment was significantly increased by removing $25 \%$ of the broom snakeweeds.

In April 1976 (9 months after treatment), soil water depletion in the 15 to $30-\mathrm{cm}$ increment was significantly $(P \leq 0.05)$ greater in the plots with one-half the normal density of snakeweeds than in the undisturbed plots (Table 3). There were no differences in soil water content at other depth increments.

In August 1976 (13 months after treatment), soil water depletion in the 15 to 30,45 to 60 and 60 to $74-\mathrm{cm}$ increments was significantly increased by complete removal of broom snakeweed $(P<0.05)$ (Table 3$)$. There was also a trend in all increments down to $75 \mathrm{~cm}$ for soil water depletion to increase as snakeweed density decreased. By this time, perennial grasses had responded to density reduction of broom snakeweed (although not linearly) and grass root systems had apparently begun to effectively utilize available water in the upper $75 \mathrm{~cm}$ of soil.

At 2 years after treatment, complete removal of broom snakeweed resulted in significant increases in soil water depletion in all increments down to $90 \mathrm{~cm}$ except the 15 to $30-\mathrm{cm}$ increment (Table 3). Removal of 25 or $50 \%$ of the broom snakeweeds did not affect soil water depletion compared to that of the undisturbed plots. As at 1 year after treatment, perennial grasses had responded to elimination of interspecific competition with broom snakeweed. Root systems of bluc grama, buffalograss, and sand dropseed [Sporobolus cryptandrus (Torr.) Gray] had apparently extended to greater depths and were effectively using soil water throughout most of the soil profile. Similar increases in soil water depletion following control of big sagebrush (Artemisia tridentata Nutt.) have been reported by Tabler (1968) and Sturges (1977).

All dates on which soil water was determined coincided with periods when most or all available soil water had been extracted by evapotranspiration. Total soil water content for the upper 120 $\mathrm{cm}$ was below the range generally considered available for plant growth for this soil, $28.7 \mathrm{~cm}$ at $-1 / 3$ bar and $15.2 \mathrm{~cm}$ at -15 bars, on all sampling dates. Only on January 13, 1976, were soil water levels for any of the depth increments within the range usually considered available. At that time, available water was present in the 0 to $15-\mathrm{cm}$ and 15 to $30-\mathrm{cm}$ depths, indicating some recharge from $0.73 \mathrm{~cm}$ of precipitation the preceding 60 days. At the October 9, 1975, sampling date, 18 days had passed without precipitation, and $8.9 \mathrm{~cm}$ had fallen in the preceding 60-day period. On the April 7, 1976, sampling date, no precipitation had been received in 30 days and only $0.6 \mathrm{~cm}$ in 60 day's. Twelve days had passed without precipitation preceding the August 18, 1976, sampling but $23.6 \mathrm{~cm}$ had fallen within 60 day's. Twenty-six days had passed without precipitation preceding the July 20, 1977 sampling, with $15.2 \mathrm{~cm}$ within 60 days. Thus, soil water is extracted to the wilting point from this soil very rapidly during summer and fall. Total precipitation during November through March periods of 1975-76 and 1976-77 was $5.2 \mathrm{~cm}$ and $5.1 \mathrm{~cm}$, respectively; therefore, little or no recharge occurred during either winter period. Soil water loss through evaporation during the hot summer months is undoubtedly very high in the study area, and might be expected to mask any small differences in water withdrawal among the treatments studied. However, the consistent pattern, at 13 months and at 2 years after treatment, of increased soil water depletion from most depth increments on broom snakeweedfree plots compared to infested plots leaves little doubt that soil water extraction by vigorous shortgrasses is greater than by dense stands of broom snakeweed.

Precipitation and Forage Production

Adequate controls (i.e., complete removal of all vegetation

Table 4. Precipitation received $(\mathrm{cm})$ and precipitation-use efficiency [forage produced $(\mathrm{kg} / \mathrm{ha}) / \mathrm{cm}$ precipitation received] of perennial grasses on broom snakeweed-infested and broom snakeweed-free shortgrass rangeland in west Texas during 1976 and 1977.

\begin{tabular}{|c|c|c|c|}
\hline \multirow[b]{2}{*}{ Year } & \multirow[b]{2}{*}{$\begin{array}{l}\text { Precipitation² } \\
(\mathrm{cm})\end{array}$} & \multicolumn{2}{|c|}{ Forage $(\mathrm{kg} / \mathrm{ha}) \mathrm{cm}$ precipitation } \\
\hline & & $\begin{array}{l}\text { Broom snakeweed } \\
\text { infested rangeland }\end{array}$ & $\begin{array}{l}\text { Broom snakeweed } \\
\text { free rangeland }\end{array}$ \\
\hline 1976 & 46.14 & 23.7 & 49.2 \\
\hline 1977 & 63.76 & 10.6 & 45.2 \\
\hline
\end{tabular}

Total precipitation received during preceding 12-month period. 
